\title{
Deoxyribonucleic Acid Homologies Among Coryneform Bacteria
}

\author{
K. SUZUKI,' T. KANEKO, ${ }^{2}$ AND K. KOMAGATA' \\ Institute of Applied Microbiology, University of Tokyo, Tokyo $113,{ }^{1}$ and Institute of Physical and Chemical \\ Research, Wako-shi, Saitama 351, Japan
}

\begin{abstract}
The deoxyribonucleic acid homologies among 33 strains of coryneform bacteria with various cell wall types reflected the previous grouping of these organisms by Yamada and Komagata on the bases of the mode of cell division, principal amino acids in the cell wall, and the base composition of deoxyribonucleic acid. In addition, the following four homology clusters were found: (i) six strains of corynebacteria with a glycolyl type of cell wall, (ii) four strains of glutamic acidproducing bacteria, (iii) two strains of Brevibacterium linens, and (iv) three strains of coryneform bacteria containing LL-diaminopimelic acid in the cell wall.
\end{abstract}

The aerobic, nonsporeforming, irregularly shaped, gram-positive rods of the genera Corynebacterium, Arthrobacter, Cellulomonas, Curtobacterium (32), Brevibacterium, and Microbacterium are referred to as coryneform bacteria (19). Phenotypic characteristics seem to be of little value in the taxonomy of coryneform bacteria, but chemotaxonomic information on the chemical composition of cells has been useful in this regard. Yamada and Komagata (33) divided coryneform bacteria into seven groups, mainly on the bases of the mode of cell division (14), principal amino acids in the cell wall (30), and deoxyribonucleic acid (DNA) base composition (32). These groupings have subsequently been supported by the cell wall peptidoglycan types (21), the phospholipid compositions of the cells (16), and the menaquinone systems $(4,29)$ of these organisms. Studies on the DNA homologies of Corynebacterium renale and phenotypically related strains (10), cheese coryneforms and soil arthrobacters (6), plant pathogenic coryneform bacteria (25), arthrobacters and brevibacteria (23), and cellulomonads (24) have been reported. However, little information is available on the DNA homology of aerobic coryneform bacteria in general.

This report deals with DNA homologies among representative strains of coryneform bacteria selected from each of the groups described by Yamada and Komagata (33) and compares the results with the chemotaxonomic characteristics of these organisms.

\section{MATERIALS AND METHODS}

Bacterial strains. The bacterial strains studied were selected from those previously studied by Komagata et al. (14) and Yamada and Komagata (30-33). A Caseobacter polymorphus strain, a species recently established by Crombach (7), was also studied. The strains studied are listed in Table 1, together with their strain numbers, several corresponding culture collection designations, and their chemotaxonomic profiles. Names which are not on the Approved Lists of Bacterial Names, 1980 (22) are enclosed within quotation marks.

As references for the DNA homology experiments, generally one strain was chosen from each group. However, for group 1, which has a wide range of DNA base compositions, four strains-Corynebacterium equi CNF 002, Corynebacterium vitarumen CNF 008 (17), Brevibacterium ammoniagenes CNF 012, and Corynebacterium glutamicum CNF 016-were selected as references. Curtobacterium citreum CNF 026 and Curtobacterium testaceum $\mathrm{CNF} 030$ were chosen as references for group 5 , in consideration of the fact that the latter is the only glycolate-positive species in group 5 (27).

Cultivation. The cultivation medium used was basically medium $R(32)$, which contained $1 \%$ peptone, $0.5 \%$ yeast extract, $0.5 \%$ Casamino Acids, $0.2 \%$ beef extract, $0.5 \%$ malt extract (all from Difco Laboratories, Detroit, Mich.), $0.2 \%$ glycerol, $0.1 \% \mathrm{MgSO}_{4} \cdot 7 \mathrm{H}_{2} \mathrm{O}$, and $0.005 \%$ Tween 80 (Wako Pure Chemical Industry Ltd., Osaka, Japan). When necessary, 0.25 to $4.0 \%$ of glycine was added to this medium to facilitate cell lysis by lysozyme (31). All organisms were grown in medium $R$ with shaking for $24 \mathrm{~h}$ at $30^{\circ} \mathrm{C}$, except for Corynebac. terium diphtheriae CNF 017 which was grown for 48 $\mathrm{h}$ at $37^{\circ} \mathrm{C}$.

Extraction of DNA. Cells collected by centrifugation were washed twice with saline-ethylenediaminetetraacetic acid $(0.15 \mathrm{M} \mathrm{NaCl}-0.1 \mathrm{M}$ ethylenediaminetetraacetic acid, $\mathrm{pH} 8.0$ ), suspended in a volume of saline-ethylenediaminetetraacetic acid equal to the cell mass, and stored in a freezer at $-20^{\circ} \mathrm{C}$. DNA was prepared- by the phenol extraction method described by Saito and Miura (20), with some minor modifications. Similarly, labeled DNA was extracted from cells grown in medium $\mathrm{R}$ supplemented with $10 \mu \mathrm{Ci}$ of [methyl- ${ }^{3} \mathrm{H}$ ] thymidine per $\mathrm{ml}$. However, since only the four reference strains of group 1 took up little [methyl- 


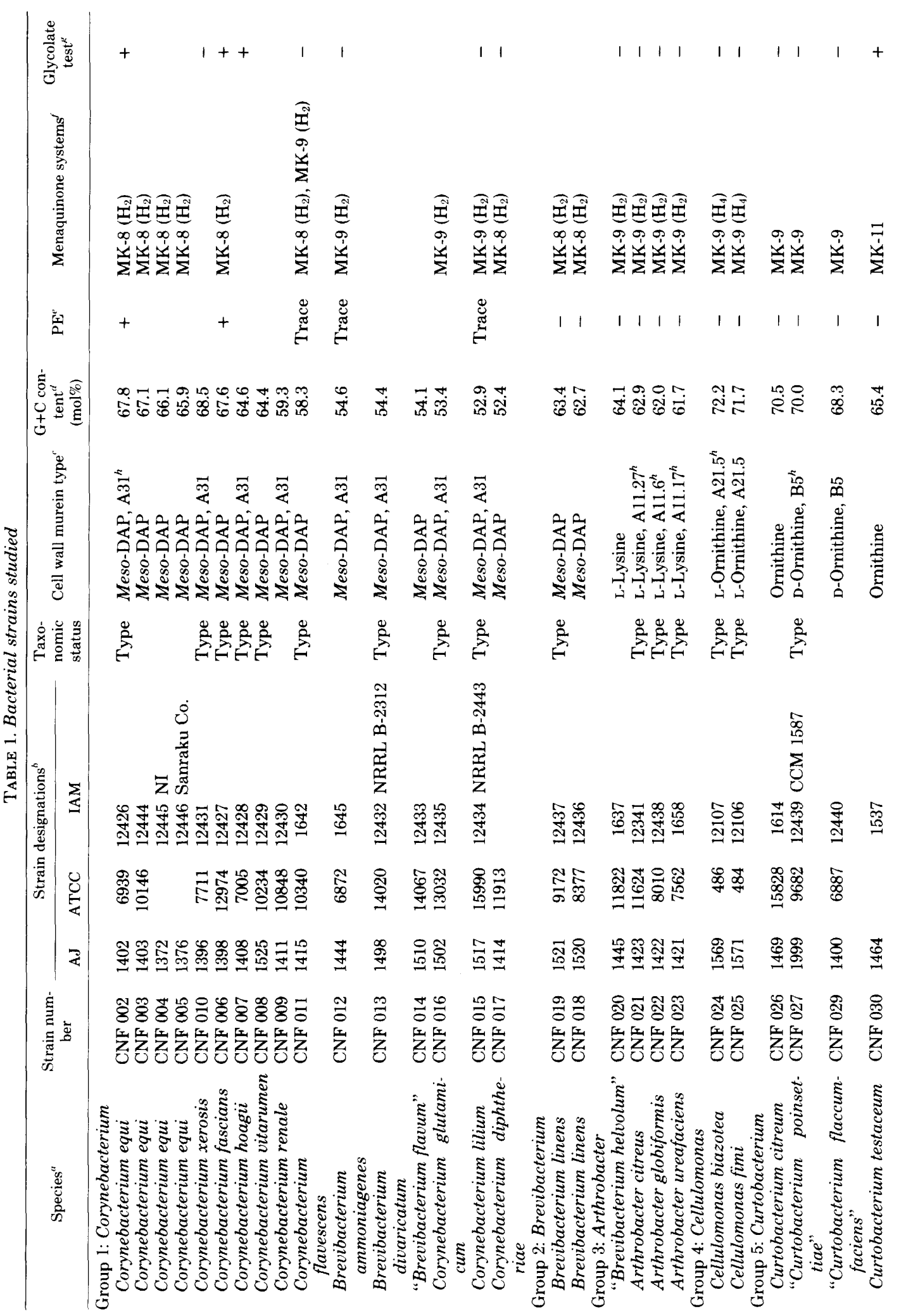




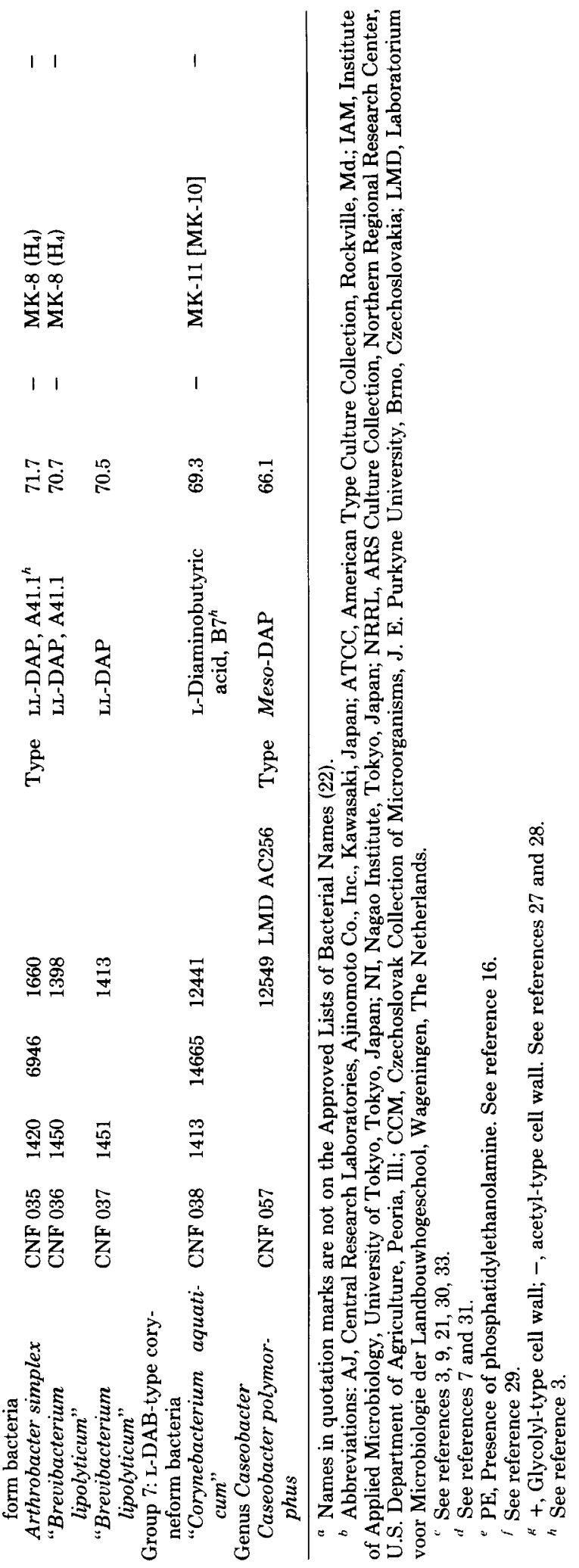


$\left.{ }^{3} \mathrm{H}\right]$ thymidine, $\left[6{ }^{3} \mathrm{H}\right]$ uracil was used instead. A similar phenomenon was observed by Honda and Yanagawa (10) with Corynebacterium renale.

DNA-DNA hybridization. DNA-DNA hybridization was carried out by the membrane filter method employed in previously reported studies $(11,13,18)$. Single-stranded DNA $(50 \mu \mathrm{g})$ was immobilized on a cellulose nitrate membrane filter (TM-2, $0.45-\mu \mathrm{m}$ pore size, 24-mm diameter; Toyo Roshi Kaisha Ltd., Tokyo). It was incubated at $62^{\circ} \mathrm{C}$ for $38 \mathrm{~h}$ in $1 \mathrm{ml}$ of $2 \times$ $\mathrm{SSC}(\mathrm{SSC}=0.15 \mathrm{M} \mathrm{NaCl}-0.015 \mathrm{M}$ trisodium citrate) containing $0.1 \%$ sodium dodecyl sulfate and approximately $5 \times 10^{3} \mathrm{cpm}$ of labeled DNA which had been heat denatured and fragmented by sonication. Incubated filters were washed twice each with $2 \times$ SSC and $5 \mathrm{mM}$ tris(hydroxymethyl)aminomethane ( $\mathrm{pH} \mathrm{9.5)} \mathrm{to}$ remove noise radioactivity (28).

The optimum hybridization temperature depends not only on the DNA base composition but also on how much the parental DNAs differ from each other (unpublished data). Because the bacterial strains used in this study differed widely, we employed a lower

TABLE 2. DNA-DNA homologies

\begin{tabular}{|c|c|c|c|c|c|c|c|c|}
\hline \multirow{3}{*}{ Species names ${ }^{\alpha}$} & \multirow{3}{*}{ Strain number } & \multirow{3}{*}{$\begin{array}{c}\mathrm{G}+\mathrm{C} \text { con- } \\
\text { tent } \\
{(\text { mol\% })^{b}}^{b}\end{array}$} & \multicolumn{6}{|c|}{ Reference strain } \\
\hline & & & \multicolumn{2}{|c|}{$\begin{array}{c}\text { C. equi CNF } \\
002\end{array}$} & \multicolumn{2}{|c|}{$\begin{array}{l}\text { C. vitarumen } \\
\text { CNF } 008\end{array}$} & \multicolumn{2}{|c|}{$\begin{array}{l}\text { B. ammonia- } \\
\text { genes CNF } 012\end{array}$} \\
\hline & & & $\mathbf{A}^{c}$ & $\mathbf{B}^{c}$ & A & B & A & $\mathrm{B}$ \\
\hline \multicolumn{9}{|l|}{ Group 1: Corynebacterium } \\
\hline Corynebacterium equi & CNF 002 & 67.8 & 100 & 100 & 43 & 11 & 5 & 3 \\
\hline Corynebacterium equi & CNF 003 & 67.1 & 95 & 91 & 44 & 12 & 6 & 3 \\
\hline Corynebacterium equi & CNF 004 & 66.1 & 95 & 85 & 33 & 9 & 6 & 3 \\
\hline Corynebacterium equi & CNF 005 & 65.9 & 91 & 88 & 31 & 11 & 5 & 3 \\
\hline Corynebacterium fascians & CNF 006 & 67.3 & 98 & 99 & 34 & 11 & 6 & 3 \\
\hline Corynebacterium hoagii & CNF 007 & 64.6 & 91 & 88 & 36 & 12 & 6 & 3 \\
\hline Corynebacterium xerosis & CNF 010 & 68.5 & 49 & 15 & 53 & 20 & 11 & 7 \\
\hline Corynebacterium vitarumen & CNF 008 & 64.4 & 34 & 14 & 100 & 100 & 13 & 8 \\
\hline Brevibacterium ammoniagenes & CNF 012 & 54.6 & 10 & 4 & 20 & 12 & 100 & 100 \\
\hline Corynebacterium renale & CNF 009 & 59.3 & 16 & 7 & 31 & 17 & 18 & 9 \\
\hline Corynebacterium flavescens & CNF 011 & 58.3 & 17 & 7 & 36 & 18 & 22 & 11 \\
\hline Corynebacterium diphtheriae & CNF 017 & 52.4 & 12 & 4 & 29 & 16 & & \\
\hline Corynebacterium divaricatum & CNF 013 & 54.4 & 9 & 4 & 26 & 13 & 22 & 10 \\
\hline "Brevibacterium flavum" & CNF 014 & 54.1 & & & 24 & 15 & 21 & 12 \\
\hline Corynebacterium lilium & CNF 015 & 52.9 & 8 & 4 & 25 & 13 & 17 & 10 \\
\hline Corynebacterium glutamicum & CNF 016 & 53.4 & 6 & 3 & 19 & 12 & 21 & 11 \\
\hline \multicolumn{9}{|l|}{ Group 2: Brevibacterium } \\
\hline Brevibacterium linens & CNF 018 & 62.7 & & & & & & \\
\hline Brevibacterium linens & CNF 019 & 63.4 & 38 & 10 & 26 & 8 & 6 & 3 \\
\hline \multicolumn{9}{|l|}{ Group 3: Arthrobacter } \\
\hline "Brevibacterium helvolum" & CNF 020 & 64.1 & & & & & & \\
\hline Arthrobacter citreus & CNF 021 & 62.9 & & & & & & \\
\hline Arthrobacter globiformis & CNF 022 & 62.0 & 26 & 8 & 24 & 8 & 6 & 3 \\
\hline Arthrobacter ureafaciens & CNF 023 & 61.7 & & & & & & \\
\hline \multicolumn{9}{|l|}{ Group 4: Cellulomonas } \\
\hline Cellulomonas biazotea & CNF 024 & 72.2 & & & & & & \\
\hline Cellulomonas fimi & CNF 025 & 71.7 & & & & & & \\
\hline \multicolumn{9}{|l|}{ Group 5: Curtobacterium } \\
\hline Curtobacterium citreum & CNF 026 & 70.5 & 44 & 11 & 28 & 7 & 4 & 2 \\
\hline "Curtobacterium poinsettiae" & CNF 027 & 70.0 & & & & & & \\
\hline "Curtobacterium flaccumfaciens" & CNF 029 & 68.3 & & & & & & \\
\hline Curtobacterium testaceum & CNF 030 & 65.4 & 40 & 12 & 36 & 9 & 4 & 2 \\
\hline \multicolumn{9}{|l|}{ Group 6: LL-DAP type coryneform bacteria } \\
\hline Arthrobacter simplex & CNF 035 & 71.7 & & & & & & \\
\hline "Brevibacterium lipolyticum" & CNF 036 & 70.7 & & & & & & \\
\hline "Brevibacterium lipolyticum" & CNF 037 & 70.5 & & & & & & \\
\hline \multicolumn{9}{|l|}{ Group 7: L-DAB type coryneform bacteria } \\
\hline "Corynebacterium aquaticum" & CNF 038 & 69.3 & 49 & 14 & 36 & 10 & 5 & 2 \\
\hline \multicolumn{9}{|l|}{ Genus Caseobacter } \\
\hline Caseobacter polymorphus & CNF 057 & 66.1 & 37 & 14 & 40 & 18 & & \\
\hline
\end{tabular}

"Names in quotation marks are not on the Approved Lists of Bacterial Names (22).

"See references 7 and 31 .

A, Homology index at $62^{\circ} \mathrm{C}$; B, homology index at $75^{\circ} \mathrm{C}$. 
incubation temperature and examined the heat stability of the hybrids $(11,18)$. Thus, after the radioactivity was counted, the filter was heated in $1 \mathrm{ml}$ of $2 \times \mathrm{SSC}$ containing $0.1 \%$ sodium dodecyl sulfate for $1 \mathrm{~h}$ at $75^{\circ} \mathrm{C}$ and washed as described above; the radioactivity remaining on the filter was then counted.

\section{RESULTS AND DISCUSSION}

In Table 2 the DNA homologies of 33 strains of coryneform bacteria with each of 11 reference strains are shown. The strains studied are arranged by the grouping of Yamada and Komagata (33); Caseobacter polymorphus is included separately. A series of our experiments $(11,13$, 18; unpublished data) suggests that the so-called "nonspecific" reaction should be practically negligible, although we did not use any negative control in this particular experiment. In each group, the homologies of the test strains with the reference strain of the group were signifi-

in coryneform bacteria

\begin{tabular}{|c|c|c|c|c|c|c|c|c|c|c|c|c|c|c|c|}
\hline \multicolumn{16}{|c|}{ Reference strain } \\
\hline \multicolumn{2}{|c|}{$\begin{array}{l}\text { C. glutamicum } \\
\text { CNF } 016\end{array}$} & \multicolumn{2}{|c|}{$\begin{array}{c}\text { B. linens } \mathrm{CNF} \\
019\end{array}$} & \multicolumn{2}{|c|}{$\begin{array}{l}\text { A. globiformis } \\
\text { CNF } 022\end{array}$} & \multicolumn{2}{|c|}{$\begin{array}{c}\text { C. fimi CNF } \\
025\end{array}$} & \multicolumn{2}{|c|}{$\begin{array}{l}\text { C. citreum } \\
\text { CNF } 026\end{array}$} & \multicolumn{2}{|c|}{$\begin{array}{l}\text { C. testaceum } \\
\text { CNF } 030\end{array}$} & \multicolumn{2}{|c|}{$\begin{array}{l}\text { A. simplex } \\
\text { CNF 035 }\end{array}$} & \multicolumn{2}{|c|}{$\begin{array}{l}\text { C. aquaticum } \\
\text { CNF } 038\end{array}$} \\
\hline A & $\mathbf{B}$ & A & B & A & $\mathrm{B}$ & A & B & A & $\mathbf{B}$ & A & B & A & $\mathrm{B}$ & A & B \\
\hline 9 & 5 & 42 & 13 & 31 & 11 & 46 & 12 & 50 & 20 & 24 & 7 & 71 & 23 & 43 & 18 \\
\hline 8 & 4 & & & & & & & & & & & & & & \\
\hline 8 & 4 & & & & & & & & & & & & & & \\
\hline 8 & 4 & & & & & & & & & & & & & & \\
\hline 8 & 5 & 34 & 13 & 31 & 10 & 49 & 13 & 52 & 22 & 26 & 7 & 78 & 29 & 48 & 15 \\
\hline 7 & 4 & 54 & 16 & 17 & 8 & 54 & 13 & 62 & 22 & 27 & 7 & 85 & 30 & 62 & 22 \\
\hline 15 & 9 & 60 & 22 & 39 & 12 & 63 & 21 & 60 & 21 & 27 & 10 & 95 & 29 & 66 & 22 \\
\hline 20 & 11 & 50 & 18 & 22 & 11 & 42 & 12 & 56 & 18 & 30 & 9 & 90 & 30 & 68 & 24 \\
\hline 24 & 13 & 16 & 6 & 10 & 4 & 9 & 3 & 8 & 4 & 9 & 3 & 16 & 6 & 12 & 4 \\
\hline 22 & 11 & 35 & 11 & 21 & 8 & 18 & 6 & 24 & 9 & 9 & 4 & 43 & 13 & 22 & 8 \\
\hline 20 & 10 & 24 & 10 & 17 & 7 & 11 & 4 & 20 & 8 & 14 & 4 & 37 & 14 & 20 & 8 \\
\hline 23 & 11 & & & & & & & & & & & & & & \\
\hline 88 & 81 & 17 & 7 & 16 & 7 & 6 & 3 & 10 & 5 & 7 & 3 & 14 & 7 & 14 & 5 \\
\hline 94 & 95 & 17 & 7 & 15 & 6 & 5 & 3 & 12 & 5 & 8 & 3 & 17 & 7 & 12 & 5 \\
\hline 99 & 101 & 19 & 8 & 13 & 6 & 8 & 3 & 12 & 6 & 8 & 3 & 14 & 7 & 11 & 5 \\
\hline \multirow[t]{2}{*}{100} & 100 & 23 & 8 & 11 & 5 & 8 & 3 & 12 & 5 & 5 & 3 & 16 & 7 & 13 & 5 \\
\hline & & 68 & 72 & 10 & 5 & 9 & 4 & 14 & 6 & 9 & 3 & 25 & 9 & 16 & 6 \\
\hline \multirow[t]{3}{*}{6} & 3 & 100 & 100 & 16 & 7 & 19 & 6 & 24 & 10 & 20 & 6 & 36 & 15 & 24 & 9 \\
\hline & & 37 & 13 & 42 & 30 & 19 & 8 & & & 13 & 6 & & & 19 & 10 \\
\hline & & 37 & 14 & 60 & 25 & 21 & 10 & 27 & 14 & 18 & 6 & 50 & 19 & 35 & 15 \\
\hline \multirow[t]{4}{*}{7} & 4 & 48 & 17 & 100 & 100 & 26 & 11 & & & 24 & 7 & & & & \\
\hline & & 24 & 9 & 38 & 24 & 17 & 7 & 16 & 8 & 12 & 5 & 25 & 12 & 18 & 9 \\
\hline & & 25 & 12 & 16 & 7 & 72 & 54 & 43 & 21 & 20 & 10 & 56 & 26 & 42 & 16 \\
\hline & & 31 & 11 & 22 & 9 & 100 & 100 & & & 31 & 12 & & & 51 & 17 \\
\hline \multirow[t]{3}{*}{5} & 3 & 52 & 18 & 32 & 10 & 76 & 26 & 100 & 100 & 33 & 15 & 83 & 35 & 67 & 26 \\
\hline & & 44 & 18 & 20 & 10 & 64 & 27 & 72 & 45 & 35 & 18 & 71 & 31 & 48 & 26 \\
\hline & & 48 & 16 & 30 & 12 & & & 77 & 48 & 39 & 15 & 72 & 26 & 66 & 31 \\
\hline \multirow[t]{4}{*}{5} & 3 & 63 & 17 & 31 & 11 & 57 & 29 & & & 100 & 100 & & & 76 & 34 \\
\hline & & 49 & 13 & 26 & 9 & 57 & 23 & 55 & 17 & 35 & 13 & 100 & 100 & 58 & 25 \\
\hline & & 40 & 15 & 29 & 9 & 66 & 28 & 59 & 18 & 42 & 14 & 100 & 100 & 59 & 23 \\
\hline & & 29 & 11 & 20 & 6 & 39 & 18 & 40 & 12 & 19 & 7 & 65 & 60 & 43 & 15 \\
\hline 6 & 3 & & & & & 72 & 32 & & & 55 & 21 & & & 100 & 100 \\
\hline 24 & 9 & & & & & & & & & & & & & & \\
\hline
\end{tabular}


cantly higher than they were with the reference strains of the other groups. In other words, no groups shared high homology indices against the reference strains from other groups, and the groups were thus clearly separated from each other by DNA homology indices. However, some groups were fairly homogeneous with respect to DNA homology, whereas others were not. The results obtained for each group are discussed below.

Group 1. In group 1, which corresponds to the genus Corynebacterium, two DNA homology clusters, as well as strains independent of these clusters, were found. One cluster comprises four Corynebacterium equi strains (CNF 002, CNF 003, CNF 004, and CNF 005), Corynebacterium fascians CNF 006, and Corynebacterium hoagii $\mathrm{CNF}$ 007. Except for $C$. fascians $\mathrm{CNF}$ 006 , which is a plant pathogen, these strains originated from animal sources (19). The members show extremely high homology (at least $88 \%$ ) at $75^{\circ} \mathrm{C}$ to the reference strain C. equi $\mathrm{CNF}$ 002 . They are also chemotaxonomically homogeneous; they all have 64.6 to $67.8 \mathrm{~mol} \%$ of guanine plus cytosine $(\mathrm{G}+\mathrm{C})$ in their DNA (31), an MK-8 $\left(\mathrm{H}_{2}\right)$ type of menaquinone (29), phosphatidylethanolamine as cellular phospholipid (16), and a glycolyl type of cell wall (27).

Corynebacterium vitarumen $\mathrm{CNF} 008$ and Corynebacterium xerosis CNF 010, which have almost the same DNA base composition as the members of the above-mentioned homology cluster, showed low indices not only to $C$. equi CNF 002 but also to C. xerosis CNF 010. These two strains have been reported to differ from the strains in the $C$. equi homology cluster with respect to the results of the glycolate test $(26$, 27 ).

The other homology cluster in group 1 consists of four strains of glutamic acid-producing bacteria. Brevibacterium divaricatum CNF 013, Brevibacterium flavum CNF 014, and Corynebacterium lilium CNF 015 showed high homology values (more than $80 \%$ ) to Corynebacterium glutamicum CNF 016. This finding suggests that on the basis of DNA homology the four strains belong to the same species. Glutamic acid-producing bacteria have been reported to resemble each other phenotypically $(1,32,33)$. It is interesting to note that Brevibacterium ammoniagenes CNF 012, which is not a glutamic acidproducing bacterium, showed a rather low homology index to C. glutamicum CNF 016, although they resemble each other phenotypically and chemotaxonomically $(16,27,29,32,33)$. Komatsu and Kaneko (15) also reported that nine strains of glutamic acid-producing bacteria fell into a single group, and that $B$. ammoniagenes ATCC 13745 was closely related to $C$. glutamicum ATCC 13032 (=CNF 016). How- ever, B. ammoniagenes ATCC 13745, studied by Komatsu and Kaneko, is a glutamic acid-producing bacterium and differs from CNF 012 (=ATCC 6872), which is one of the original strains of $B$. ammoniagenes on which Cooke and Keith established the species (5).

Corynebacterium diphtheriae CNF 017, Corynebacterium flavescens $\mathrm{CNF} 011$, and Corynebacterium renale CNF 009 were not related to glutamic acid-producing bacteria or to $B$. ammoniagenes $\mathrm{CNF} 012$. In the eighth edition of Bergey's Manual of Determinative Bacteriology (19), these three species are placed in "Section I. Human and animal parasites and pathogens," corresponding to "Corynebacterium sensu stricto" (12). Glutamic acid-producing bacteria, on the other hand, are accommodated by "Section III. Non-pathogenic corynebacteria." In this study, we did not determine the similarities among the three strains mentioned above, but their indices of DNA homology suggest that the organisms are rather closely related to each other. Recently, Barksdale et al. (2) transferred Microbacterium flavum to the genus Corynebacterium, recognized a new species, $C$. flavescens, and reported a high homology value (64\%) for C. flavescens and C. diphtheriae.

Corynebacteria, in a broad sense, generally have cell walls containing meso-diaminopimelic acid (meso-DAP) and arabinogalactan (21), but their DNA base compositions vary widely from 52 to $70 \mathrm{~mol} \% \mathrm{G}+\mathrm{C}$ (31). Crombach pointed out that this range is too wide to consider the corynebacteria as belonging to one genus (8). The present data also suggest that the species of the genus Corynebacterium be divided into more than four subgroups.

Group 2. Group 2 corresponds to the genus Brevibacterium. Brevibacterium linens CNF 018 had $70 \%$ DNA homology to the type strain, $B$. linens CNF 019. Although these strains have meso-DAP in their cell walls $(21,30)$, they did not relate any more closely to the members of group 1 than to those of the other groups whose members do not contain meso-DAP.

Group 3. Group 3 contains arthrobacters which have L-lysine in their cell walls (30). This group was found to have DNA heterogeneous with that of Arthrobacter globiformis CNF 022, the type species of the genus. Recently, Stackebrandt and Fiedler (23) studied the relationship between DNA homology and peptidoglycan in arthrobacters; they reported that arthrobacters are rather diverse even when they share the same peptidoglycan type in their cell walls.

Group 4. Group 4 contains the cellulomonads. Cellulomonas fimi CNF 025 was used as a reference strain. This strain has such a high $\mathrm{G}+\mathrm{C}$ content that the homology indices with some strains with high $\mathrm{G}+\mathrm{C}$ contents were themselves 
quite high. Cellulomonas biazotea CNF 024 showed 54\% homology to the reference strain, whereas the strains of the other groups studied showed approximately $30 \%$ or lower homology values. These homology values distinguished cellulomonads from other coryneform bacteria, and the moderate similarity between $C$. fimi CNF 025 and $C$. biazotea CNF 024 revealed that they belong to the same genus.

Group 5. This group contains the curtobacteria. The genus Curtobacterium, which was established by Yamada and Komagata (33), is composed mainly of motile brevibacteria from plants and seems to be rather homogeneous morphologically and physiologically $(32,33)$. However, high homology values were not found among the strains in this group. Curtobacterium testaceum CNF 030 showed exceptionally low relatedness to the other members of this group. The distinctiveness of this species was indicated not only by the results of the glycolate test (26, 27) and menaquinone system (29) but also by DNA homology results.

Group 6. The members of group 6 contain LL-DAP and glycine in their cell walls $(21,30)$, and their DNA base compositions are concentrated in a narrow range ( 70 to $72 \mathrm{~mol} \% \mathrm{G}+\mathrm{C}$ ). The result of the hybridization test at $75^{\circ} \mathrm{C}$ with Arthrobacter simplex CNF 035 as a reference strain showed $100 \%$ homology to Brevibacterium lipolyticum CNF 036 and $60 \%$ to B. lipolyticum CNF 037. These indices are high enough to separate them from others which showed low values (not more than $35 \%$ ) and suggest that these three strains belong to one species.

Group 7. Corynebacterium aquaticum $\mathrm{CNF}$ 038 , a member of group 7, was found to contain L-diaminobutyric acid in its cell wall and to have low homology indices with strains of the other groups, thus revealing that group 7 is unique.

Crombach (7) proposed a new genus, Caseobacter, for non-orange cheese coryneforms based on the fact that they are not "parasitic or pathogenic diphtheroids of human and animal origin" and that their $\mathrm{G}+\mathrm{C}$ contents are $10 \%$ higher than that of Corynebacterium diphtheriae, the type species of the genus Corynebacterium. He reported the low DNA relatedness of caseobacters to $B$. linens and $A$. globiformis, but the DNA homology between Caseobacter polymor. phus and other corynebacteria had not then been determined. In the present study, C. polymorphus CNF 057 appeared to be similar to $C$. vitarumen $\mathrm{CNF} 008$ and $C$. xerosis $\mathrm{CNF} 010$ with respect to their homology patterns with some reference strains of corynebacteria. The homology index between C. polymorphus CNF 057 and C. vitarumen $\mathrm{CNF} 008$ was rather low, although these organisms have almost the same
DNA base composition. Further chemotaxonomy and DNA homology studies will help to clarify the relationships of these strains.

In this study, we found good agreement between the DNA homologies and the chemotaxonomic profiles reported to date for the coryneform bacteria; we also confirmed that chemotaxonomic characters are useful in the classification of this group of bacteria at the generic level. The type of peptidoglycan in the cell wall is one of the most important criteria for defining the genera of coryneform bacteria, but Stackebrandt and Fiedler (23) showed that there is a problem in defining species of Arthrobacter either by interpeptide bridge types or by DNA homologies. Moreover, Stackebrandt and Kandler (24) proposed neotype strains for seven Cellulomonas species on the basis of DNA homology and some phenotypic characteristics, thus dividing the genus still further.

In a previous paper (11), we pointed out the practical application of DNA homology in the identification of biovars of Pseudomonas mal. tophilia. The result of the study reported here should be helpful in defining species of coryneform bacteria, although we feel that additional systematic studies are required for this purpose.

\section{ACKNOWLEDGMENTS}

We thank K. Yamada, Central Research Laboratories, Ajinomoto Co., Inc., Kawasaki, Japan, and W. H. J. Crombach, Laboratory of Microbiology, Agricultural University, Wageningen, The Netherlands, for kindly supplying cultures.

\section{REPRINT REQUESTS}

Address reprint requests to: Dr. K. Komagata, Institute of Applied Microbiology, University of Tokyo, Bunkyo-ku, Tokyo 113, Japan.

\section{LITERATURE CITED}

1. Abe, S., K. Takayama, and S. Kinoshita. 1967. Taxonomical studies on glutamic acid-producing bacteria. J. Gen. Appl. Microbiol. 13:279-301.

2. Barksdale, L., M. A. Lanéelle, M. C. Pollice, J. Asselineau, M. Welby, and M. V. Norgard. 1979. Biological and chemical basis for the reclassification of Microbacterium flavum Orla-Jensen as Corynebacterium flavescens nom. nov. Int. J. Syst. Bacteriol. 29:222-233.

3. Claus, D., and C. Schaab-Engels (ed.). 1977. Deutsche Sammlung von Mikroorganismen, catalogue of strains, 2nd ed. Gesellschaft für Strahlen und Umweltforschung $\mathrm{mbH}$, München, West Germany.

4. Collins, M. D., T. Pirouz, and M. Goodfellow. 1977. Distribution of menaquinones in actinomycetes and corynebacteria. J. Gen. Microbiol. 100:221-230.

5. Cooke, J. V., and H. R. Keith. 1927. A type of ureasplitting bacterium found in the human intestinal tract. J. Bacteriol. 13:315-319.

6. Crombach, W. H. J. 1974. Relationships among coryneform bacteria from soil, cheese and sea fish. Antonie van Leeuwenhoek J. Microbiol. Serol. 40:347-359.

7. Crombach, W. H. J. 1978. Caseobacter polymorphus gen. nov., sp. nov., a coryneform bacterium from cheese. Int. J. Syst. Bacteriol. 28:354-366. 
8. Crombach, W. H. J. 1978. DNA base ratios and DNA hybridisation studies of coryneform bacteria, mycobacteria, and nocardiae, p. 161-179. In I. J. Bousfield and A. G. Callely (ed.), Coryneform bacteria. Academic Press, Inc., London.

9. Fiedler, F., and O. Kandler. 1973. Die Mureintypen in der Gattung Cellulomonas Bergey et al. Arch. Mikrobiol. 89:41-50.

10. Honda, E., and R. Yanagawa. 1973. Deoxyribonucleic acid homologies among three immunological types of Corynebacterium renale (Migula) Ernst. Int. J. Syst. Bacteriol. 23:226-230.

11. Ikemoto, S., K. Suzuki, T. Kaneko, and K. Komagata. 1980. Characterization of strains of Pseudomonas maltophilia which do not require methionine. Int. J. Syst. Bacteriol. 30:437-447.

12. Jensen, H. L. 1952. The coryneform bacteria. Annu. Rev. Microbiol. 6:77-90.

13. Kaneko, T., R. Nozaki, and K. Aizawa. 1978. Deoxyribonucleic acid relatedness between Bacillus anthracis, Bacillus cereus, and Bacillus thuringiensis. Microbiol. Immunol. 22:639-641.

14. Komagata, K., K. Yamada, and H. Ogawa. 1969. Taxonomic studies on coryneform bacteria I. Division of bacterial cells. J. Gen. Appl. Microbiol. 15:243-259.

15. Komatsu, Y., and T. Kaneko. 1980. Deoxyribonucleic acid relatedness between some glutamic acid-producing bacteria. Report of the Fermentation Research Institute, Tsukuba, Japan 55:1-5.

16. Komura, I., K. Yamada, S. Otsuka, and K. Komagata. 1975. Taxonomic significance of phospholipids in coryneform and nocardioform bacteria. J. Gen. Appl. Microbiol. 22:251-261.

17. Lanéelle, M. A., J. Asselineau, M. Welby, M. V. Norgard, T. Imaeda, M. C. Pollice, and L. Barksdale. 1980. Biological and chemical bases for the reclassification of Brevibacterium vitarumen (Bechdel et al.) Breed (Approved Lists, 1980) as Corynebacterium vi tarumen (Bechdel et al.) comb. nov. and Brevibacter. ium liquefaciens Okabayashi and Masuo (Approved Lists, 1980) as Corynebacterium liquefaciens (Okabayashi and Masuo) comb. nov. Int. J. Syst. Bacteriol. 30: 539-546.

18. O'Donnel, A. G., J. R. Norris, R. C. W. Berkeley, D. Claus, T. Kaneko, N. A. Logan, and R. Nozaki. 1980. Characterization of Bacillus subtilis, Bacillus pumilus, Bacillus licheniformis, and Bacillus amyloliquefaciens by pyrolysis gas-liquid chromatography, deoxyribonucleic acid-deoxyribonucleic acid hybridization, biochemical tests, and API systems. Int. J. Syst. Bacteriol. 30:448-459.

19. Rogosa, M., C. S. Cummins, R. A. Lelliot, and R. M. Keddie. 1974. Coryneform group of bacteria, p. 599-
617. In R. E. Buchanan and N. E. Gibbons (ed.), Bergey's manual of determinative bacteriology, 8 th ed. The Williams \& Wilkins Co., Baltimore.

20. Saito, H., and K. Miura. 1963. Preparation of transforming deoxyribonucleic acid by phenol treatment Biochim. Biophys. Acta 72:619-629.

21. Schleifer, K. H., and O. Kandler. 1972. Peptidoglycan types of bacterial cell walls and their taxonomic implications. Bacteriol. Rev. 36:407-477.

22. Skerman, B. V. D., V. McGowan, and P. H. A. Sneath (ed.). 1980. Approved lists of bacterial names. Int. J. Syst. Bacteriol. 30:224-420.

23. Stackebrandt, E., and F. Fiedler. 1979. DNA-DNA homology studies among strains of Arthrobacter and Brevibacterium. Arch. Microbiol. 120:289-295.

24. Stackebrandt, E., and O. Kandler. 1979. Taxonomy of the genus Cellulomonas, based on phenotypic characters and deoxyribonucleic acid-deoxyribonucleic acid homology, and proposal of seven neotype strains. Int. J. Syst. Bacteriol. 29:273-282.

25. Starr, M. P., M. Mandel, and N. Murata. 1975. The phytopathogenic coryneform bacteria in the light of DNA base composition and DNA-DNA segmental homology. J. Gen. Appl. Microbiol. 21:13-26.

26. Uchida, K., and K. Aida. 1977. Acyl type of bacterial cell wall: its simple identification by colorimetric method. J. Gen. Appl. Microbiol. 23:249-260.

27. Uchida, K., and K. Aida. 1979. Taxonomic significance of cell-wall acyl type in Corynebacterium-Mycobacte rium-Nocardia group by a glycolate test. J. Gen. Appl. Microbiol. 25:169-183.

28. Warnaar, S. O., and J. A. Cohen. 1966. A quantitative assay for DNA-DNA hybrids using membrane filters. Biochem. Biophys. Res. Commun. 24:554-558.

29. Yamada, Y., G. Inoue, Y. Tahara, and K. Kondo. 1976. The menaquinone system in the classification of coryneform and nocardioform bacteria and related organisms. J. Gen. Appl. Microbiol. 22:203-214.

30. Yamada, K., and K. Komagata. 1970. Taxonomic studies on coryneform bacteria II. Principal amino acids in the cell wall and their taxonomic significance. J. Gen. Appl. Microbiol. 16:103-113.

31. Yamada, K., and K. Komagata. 1970. Taxonomic studies on coryneform bacteria III. DNA base composition of coryneform bacteria. J. Gen. Appl. Microbiol. 16: 215-224.

32. Yamada, K., and K. Komagata. 1972. Taxonomic studies on coryneform bacteria IV. Morphological, cultural, biochemical, and physiological characteristics. J. Gen. Appl. Microbiol. 18:399-416.

33. Yamada, K., and K. Komagata. 1972. Taxonomic studies on coryneform bacteria V. Classification of coryneform bacteria. J. Gen. Appl. Microbiol. 18:417-431. 